\title{
Mobilizing Private Landowners to Create American Woodcock Habitat: Lessons Learned in Rhode Island, USA
}

BILL BUFFUM, ${ }^{1}$ University of Rhode Island, Department of Natural Resources Science, ${ }_{13}$ Coastal Institute in Kingston, Kingston, RI 02881, USA

BRIAN C. TEFFT, ${ }^{2}$ Rhode Island Department of Environmental Management, Division of Fish and Wildlife, 277 Great Neck Road, West Kingston, RI 02892, USA

ROGER J. MASSE, ${ }^{3}$ University of Rhode Island, Department of Natural Resources Science, 102 Coastal Institute in Kingston, Kingston, RI 02881, USA

SCOTT R. MCWILLIAMS, University of Rhode Island, Department of Natural Resources Science, 102 Coastal Institute in Kingston, Kingston, RI 02881, USA

\begin{abstract}
Engaging private landowners in the conservation of American woodcock (Scolopax minor; hereafter, woodcock) in the northeastern United States is important because most forests in the region are privately owned. For this reason, a consortium of conservation agencies in the region has been encouraging private landowners to create young forest vegetation types. This study summarizes the achievements and lessons learned through 3 components of a collaborative outreach program as practiced in Rhode Island, USA since 2008: 1) providing technical and financial assistance to private landowners to support woodcock habitat creation, 2) developing a woodcock management demonstration area in the Great Swamp Wildlife Management Area to support research and landowner trainings, and 3) conducting research on landowner involvement in the creation of young forest. We found that the financial and technical assistance was an important factor motivating private landowners to create young forest. Furthermore, response to a follow-up questionnaire after our trainings was encouraging; $83 \%$ of the participants followed up with forest management on their own properties, and creation of young forest was the most common activity. The woodcock demonstration area strongly supported the training programs by allowing landowners to see regenerating clearcuts of 4 different ages in close proximity, and it was used as a research site to determine how woodcock selected certain-aged young forest patches. Our spatial analysis confirmed that the extent of young forest created in Rhode Island during the 7 years after 2004 was almost double the extent created during the previous 7 years, and that private landowners created more habitat than either government agencies or nongovernment organizations. We conclude that private landowners can play an important role in the conservation of woodcock, and recommend an expanded outreach program to mobilize them.
\end{abstract}

Proceedings of the American Woodcock Symposium 11: 85-92

KEY WORDS: American woodcock, clearcutting, early successional forest, forestry demonstration, private landowners, spatial analysis

1 corresponding author: buffum@uri.edu

2 retired

3 current affiliation: State University of New York at Cobleskill, Fisheries, Wildlife,

and Environmental Science Department, Cobleskill, NY 12043, USA 
American woodcock (Scolopax minor; hereafter, woodcock) populations in the eastern United States have declined by roughly $1 \%$ per year since 1968 (Cooper and Rau 2013), a decline linked to the loss of young forest vegetation types (McAully et al. 2005, Kelly et al. 2008). Private landowners are critical to the conservation of woodcock in southern New England, where private ownership of forests is $77 \%$ in Connecticut, $79 \%$ in Massachusetts, and $85 \%$ in Rhode Island (Butler et al. 2011). For this reason, a consortium of federal, state, university, and private conservation agencies in Rhode Island has been collaborating since 2008 to encourage private landowners to create habitat for woodcock and other species that require young forests.

The consortium is led by 4 agencies-the Rhode Island Department of Environmental Management (RIDEM), the University of Rhode Island (URI), the USDA Natural Resources Conservation Service (NRCS), and the Rhode Island Resource Conservation and Area Development Council (RC\&D)-and has received valuable support from several other agencies, including the USDA National Institute of Food and Agriculture (through URI Agricultural Experiment Station), the RI Forest Conservators Organization, and the Ruffed Grouse Society. The program has included 3 main components: 1) providing technical and financial support to motivate private landowners to create young forests on their properties, 2) creating a 40-ha woodcock management demonstration area for research and training purposes, and 3) conducting research on landowner involvement in the creation of young forests. The purpose of this manuscript is to document the lessons learned through this integrated program and to offer recommendations for an expanded outreach program to private landowners in the northeastern United States.

\section{Study Area}

Our study area for our larger-scale spatial analyses and for engaging private landowners in forest management included the state of Rhode Island. Our study also focused on the 40-ha woodcock management demonstration area in the Great Swamp Wildlife Management Area, South Kingstown, Rhode Island, USA. The RIDEM Division of Fish and Wildlife initiated forest cutting in 1995 within an area that was formally designated in 2008 as a woodcock habitat demonstration area. RIDEM created this demonstration area to support the Woodcock Conservation Plan for New England/New York, which proposed developing demonstration areas on public lands to showcase exemplary habitat management for woodcock and other young-forest-dependent wildlife (Williamson 2008). RIDEM selected the Great Swamp Wildlife Management Area for this demonstration area because its approximately 1,050 ha of wetland forest and 325 ha of upland forest were largely in older age classes (6o to 100 years old). The stated objectives for the Rhode Island woodcock demonstration area were to: 1) manage young forest vegetation types for woodcock and other wildlife, using Best Management Practices, 2) monitor woodcock and songbird response to habitat management, 3) measure key habitat features, and 4) create educational materials and opportunities for private landowners. Given the importance of this demonstration area for landowner training and research, we briefly describe in the Results how the demonstration area was developed and how it has been utilized.

\section{Methods}

\section{TECHNICAL AND FINANCIAL SUPPORT} TO PRIVATE LANDOWNERS

The consortium organized a number of training events each year for private landowners, including the annual Rhode Island Coverts Workshop, a 3-day event that included classroom and field-based training related to creating young forests. We also encouraged private landowners to apply for technical and financial support from the NRCS Environmental Quality Incentives Program (NRCS 2017) and the URI-NRCS Regional Conservation Partnership Program (URI 2017). In 2014, we conducted a survey of private landowners who created young forests after having participated in a Rhode Island Coverts Workshop between 2008 and 2012 (Buffum et al. 2014). We provide a summary of these survey findings and a follow-up analysis of NRCS technical and financial support targeted to create young forest.

\section{SPATIAL ANALYSIS OF YOUNG FOREST VEGETATION}

Our spatial analysis compared the extent of young forest vegetation created in Rhode Island during 2 7-year periods (1997-2004 and 2004-2011) by private landowners, government agencies, and non-government organizations. We used ArcGIS version 10.4.1 (Environmental Systems Research Institute, Redlands, CA) with datasets and imagery that are publicly available on the Rhode Island Geographic Information System (RIGIS 2017); land use/land cover (1997, 2004 and 2011); conservation status (2014); and imagery (1997, 2004, 2008, 2011, 2016). We identified parcels with an area $\geq 1$ ha that were classified as forest in 2004 and as non-forest in 2011. We used the 2004 and 2011 imagery to confirm that the plots had been clearcut. We used the 2016 imagery to exclude plots that had already been converted to land uses other than young forest by 2016. Finally, we classified the ownership status of the remaining young forest plots into 6 categories of conservation land (state, federal, municipal, land trust, non-governmental organization [NGO], private) and 1 category of non-conservation land. We compared the results to data from a previous study that used a similar approach to assess the extent of young forest vegetation types created between 1997 and 2004 (Buffum et al. 2011). 


\section{Results}

\section{SUPPORT TO PRIVATE LANDOWNERS}

Follow up by private landowners after attending our trainings was encouraging-our survey found that $83 \%$ of landowners who had attended the Coverts Workshop $\geq 6$ months before the survey had already followed up by preparing a management plan or implementing forestry activities on their properties, with the most common activity being the creation of young forest (Buffum et al. 2014). The main factor affecting how quickly they implemented forest management activities after the training appeared to be whether they had completed a forest management plan, a process that can take up to a year. Eighty percent of participants with management plans had already implemented some forest management activities.

The size of forest holdings did not affect the likelihood of follow-up after the training. Participants owning $\geq 20$ ha of forest mentioned several advantages of having larger forest holdings when creating young forest vegetation types: greater flexibility in site selection, fewer conflicts with neighbors who do not like clearcuts near their property boundaries, and greater ability to engage loggers who often prefer larger jobs. Participants with smaller holdings were less likely to be interested in earning income from their forests or to have sold timber or firewood. However, they were equally likely to have conducted forest management before attending the training, and to have followed up after attending the training.

Landowner awareness about the importance of young forests was low. All of our training participants had a strong interest in wildlife, but few were aware before attending the training that so many wildlife species depended on young forests or that this vegetation type was declining in New England. Many viewed clearcutting negatively, and $33 \%$ said they probably would not have implemented any clearcuts if they had not attended the training. Financial and technical assistance from NRCS was an important motivating factor; $84 \%$ of the landowners who implemented activities after attending the Coverts Workshop received support from NRCS, and $47 \%$ said they would probably not have implemented the activities without the financial assistance. However, many participants were not aware about NRCS financial assistance programs before attending our training.

\section{WOODCOCK DEMONSTRATION AREA}

After the plan for the woodcock demonstration area was formally submitted in 2008, RIDEM almost tripled the extent of young forest vegetation to 33.17 ha with 4 more clearcuts in 2012 and 2017 (Table 1 and Fig. 1). The aim was to create a mosaic of young forest stands of different ages adjacent to mature forest and open fields. The planned clearcuts were marked by wildlife biologists and foresters, and offered for sale at open bid to local commercial loggers.
The payments from the loggers covered all of the costs of the habitat-creation program. The loggers were instructed to leave 1-2 mast-producing trees per ha as a food source for wildlife and 1-2 standing dead snags per ha as habitat for cavity nesters. All downed woody debris was retained on-site scattered or in small brush piles. As our experience grew, we planned larger patch cuts $(>4$ ha each) and reduced the stand reentry time to accomplish our original goal of a 25 -year rotation for the entire area. For more information about the site, see Timberdoodle.org (2017).

Initially we encountered some opposition to creating these clearcuts, the purpose of which was misunderstood by some citizens who visited the area for recreational purposes. We responded to these complaints through educational presentations about the habitat program, stressing that the clearcuts were necessary to preserve biodiversity within the management area by creating young forests that so many wildlife species depend upon.

RIDEM and URI started a pilot research program in 2008 to examine the impact of the young forest management on woodcock and other bird species (Masse et al. 2013, Masse et al. 2014, 2015). In brief, we captured male woodcock on their singing grounds and fitted them with backpack-style transmitters. The telemetry data included locations, movements, survival, and habitat use by woodcock, expanding knowledge of local woodcock and the impact of the demonstration area. Basic home-range and habitat-use data included dominant forest type used, age class, stem density, overstory density, and earthworm biomass. We also used point-count surveys to assess the impact of habitat management on other high-priority avian species.

We determined that all of the habitat needs of woodcock residing in the Great Swamp Wildlife Management Area during spring through fall could be met because roosting meadows, daytime feeding areas, and singing grounds were available. Some important findings were that

Table 1. Timing and combined area of young forest habitat patches produced by Rhode Island Department of Environmental Management Division of Fish and Wildlife as part of the creation of an ca. 40-ha woodcock management demonstration area in the state-owned Great Swamp Wildlife Management Area, South Kingstown, Rhode Island.

\begin{tabular}{ccc}
\hline Year & Hectares & Number Plots \\
\hline 1995 & 4.63 & 3 \\
2007 & 8.50 & 3 \\
2012 & 9.81 & 2 \\
2017 & 10.24 & 2 \\
Total & 33.17 & 10 \\
\hline
\end{tabular}


1) $83 \%$ of the daytime feeding areas were located in wetland deciduous forests, 2) average stem density within home ranges was 9,500 stems per ha, and 3) earthworm biomass was significantly higher within home ranges than in other nearby forests. The importance of the habitat management for other avian species was an additional benefit that supported the habitat management program goals, as 39 species of birds were identified using the managed areas, including several species of high conservation concern.

We used the demonstration area to educate university wildlife classes, visiting scientists and symposiums, and private citizen forestry associations, and for targeted private landowner outreach programs such as the Rhode Island Coverts Workshop. The demonstration area allows our team of scientists to communicate directly with private landowners about the impact they can have on wildlife by employing basic habitat management practices on their properties. We plan to install a series of interpretive signs to further educate the public about woodcock habitat requirements. URI graduate students and faculty are working with RIDEM to design interpretive signs with information about woodcock roosting grounds (Fig. S1), singing grounds, feeding grounds, nesting cover, and other topics (Monahan 2012).

\section{SPATIAL ANALYSIS OF YOUNG FOREST COVER TYPES}

The amount of young forest created in clearcuts of $\geq 1$ ha in Rhode Island increased from 37.9 ha/year during the period of 1997-2004 to 73.9 ha/year during the period of 2004-2011 (Table 2). In both periods, most of the young forest was created on privately-owned land without any conservation status, which applies to most landowners who apply for NRCS support. Most of the young forest produced on conservation lands was created by municipal organizations during the first period, and by the State of

Table 2. Amount of young forest created in Rhode Island between 1997-2004 and 2004-2011 by fee ownership type based on clearcuts of $\geq 1$ ha that had not been converted to non-forest land use 5 years after the end of the period.

\begin{tabular}{llrcrc}
\hline \multirow{2}{*}{ Fee Ownership } & \multirow{2}{*}{ Conservation Status } & \multicolumn{2}{c}{ 1997-2004 } & \multicolumn{2}{c}{ 2004-2011 } \\
& & $\mathrm{Ha}$ & \% of total & \multicolumn{1}{c}{ Ha } & \% of total \\
\hline State & Conserved & 7.4 & 3 & 55.4 & 11 \\
Federal & Conserved & 0.0 & 0 & 2.7 & 1 \\
Land Trust & Conserved & 8.6 & 3 & 7.0 & 1 \\
Municipal & Conserved & 81.4 & 31 & 49.3 & 10 \\
NGO & Conserved & 0.3 & 0 & 20.1 & 4 \\
Private & Conserved & 3.6 & 1 & 3.6 & 1 \\
Private & Non-conserved & 164.1 & 62 & 378.9 & 73 \\
Total & & 265.3 & 100 & 517.0 & 100 \\
\hline Total per year & & 37.9 & & 73.9 & \\
\hline
\end{tabular}

Rhode Island in the second period. In both periods, most of the young forest that was subsequently converted to other land uses was for residential and commercial construction, with much smaller amounts used for agriculture, gravel mines, and lawns. Most of these conversions took place within a few years; our analysis of the 2016 imagery revealed that only $7 \%$ of the young forest created between 1997-2004 that was still forest in 2008 was converted to other land uses by 2016 .

These findings on the extent of young forest created on state land are consistent with data compiled by RIDEM, which show that the extent of clearcuts on state land increased considerably after 2004 (Fig. 2). This trend can be expected to continue due to planned clearcuts in 2018 and 2019 at the same level as the 2017 cuts. NRCS support to private landowners for creating young forest in Rhode Island also increased since 2006. The annual extent of young forest created by private landowners with support from NRCS for early successional habitat practices during 2012-2017 was almost 3 times the annual extent during 2006-2011.

\section{Discussion}

Our findings highlight the importance of educating landowners about the value of young forest cover types for wildlife. Awareness of this issue before attending the training was unexpectedly low, considering that the participants already had strong interest in wildlife. This applied to several participants who had already prepared forest management plans before attending the training, which suggests that their consulting foresters did not stress the importance of creating young forest during the process of plan preparation. Thus, we believe that consulting foresters as well as landowners could benefit from training about the ecological importance of young forests. This is especially important considering that many landowners have negative perceptions about clearcutting (Berlick et al. 2002).

Our findings also suggest an opportunity for outreach programs in southern New England to target landowners with small forest holdings. Other studies have reported correlations between larger forest holdings and more active forest management (Rickenbach and Kittredge 2009) and greater participation in forestry programs (Poudyal and Hodges 2009, Ma et al. 2012). However, our participants with smaller holdings were equally likely to 
follow up with management practices on their properties after the training. We believe that landowners with small holdings can make a valuable contribution by creating woodcock singing grounds, which can be achieved with clearcuts as small as 0.2 ha (Kelley et al. 2008), although cuts $\geq 0.6$ ha would also provide suitable habitat for many shrubland bird species (Askins et al. 2007). Landowners with small holdings can also support wildlife species such as New England cottontail (Sylvilagus transitionalis) that require much larger habitat patches if their properties are near existing patches of young forest (Buffum 2016).

The financial and technical assistance offered by NRCS was an important motivating factor for the landowners who attended our training sessions. We agree with Daniels et al. (2010), who reported that profit was not the primary objective of many landowners, but that the financial incentives increased the area of forest owners were willing to manage. We strongly endorse the current NRCS program of providing financial support for the preparation of forest management plans, an important first step in creating wildlife habitat. We recommend that these important technical and financial assistance programs be promoted more widely, and that simpler descriptions of NRCS forestry programs and application procedures be developed.

The woodcock demonstration area has been extremely valuable for our outreach program because it allows landowners to see regenerating clearcuts of 4 different ages in close proximity, which makes them much more comfortable with the idea of clearcutting. The scale of habitat management in the demonstration area can be intimidating for some private landowners, but our training sessions also include visits to private landowners who have implemented smaller-scale habitat-creation activities. Several authors have emphasized the benefits of peer-to-peer learning as an effective approach to motivate landowners (Rickenbach and Kittredge 2009, Ma et al. 2012). We believe that exposing participants in our training sessions to both small- and large-scale habitat management activities is an effective strategy, and the feedback from those who attended training sessions has been highly favorable.

We are far from creating the amount of young forest in Rhode Island that wildlife biologists have recommended to stabilize populations of woodcock and other species that require this vegetation type. For example, Dettmers and Rosenberg (2000) proposed addressing population objectives for priority shrubland bird species by maintaining young forest on $10 \%$ of forests in southern New England, which is almost double the current extent in Rhode Island (Buffum et al. 2011). The 2008 Woodcock Conservation Plan proposed an even more ambitious program of maintaining shrubland and young forest on $27 \%$ of forests in Rhode Island, which would require a greatly increased amount of clearcutting. Nevertheless, we were encouraged to see that the amount of young forest created per year in
Rhode Island doubled after 2004, and that most of this increase was due to the efforts of private landowners. We cannot attribute all of this increase to the efforts of our consortium, but we are confident that our integrated program has made a positive contribution and that further increases are possible if we intensify our efforts. It is also clear that private landowners can play an important role in the conservation of woodcock in our region and elsewhere, and we recommend an expanded outreach program to mobilize them.

\section{Acknowledgments}

We are grateful to the anonymous reviewers for their comments on the manuscript. This work was supported by the University of Rhode Island and the Rhode Island Department of Environmental Management (Award 3394024). It is contribution \#5473 of the University of Rhode Island Agricultural Experiment Station.

\section{Literature Cited}

Askins, R.A., B. Zuckerberg, and L. Novak. 2007. Do the size and landscape context of forest openings influence the abundance and breeding success of shrubland songbirds in southern New England? Forest Ecology and Management 250:137-147.

Berlick, M.M., D.B. Kittredge, and D.R. Forest. 2002. The illusion of preservation - a global environmental argument for the local production of natural resources. Harvard Forest Paper 26. Harvard Forest, Harvard University, Petersham, Massachusetts, USA.

Buffum, B. 2016. Identifying sites where small clearcuts can expand habitat for New England cottontail in conjunction with existing habitat patches in Rhode Island. University of Rhode Island, Department of Natural Resources, Kingston, Rhode Island, USA

Buffum, B., S.R. McWilliams, and P.V. August. 2011. A spatial analysis of forest management and its contribution to maintaining the extent of shrubland habitat in southern New England, United States. Forest Ecology and Management 262:1775-1785.

Buffum, B., C. Modisette, and S. McWilliams. 2014. Encouraging family forest owners to create early successional wildlife habitat in southern New England. PLoS ONE 9:6.

Butler, B.J., C.J. Barnett, S.J. Crocker, G.M. Domke, D. Gormanson, W.N. Hill, C.M. Kurtz, T. Lister, C. Martin, P.D. Miles, R. Morin, W.K. Moser, M.D. Nelson, B. O'Connell, B. Payton, C.H. Perry, R.J. Piva, R. Riemann, and C.W. Woodall. 2011. The forests of southern New England, 2007: a report on the forest resources of Connecticut, Massachusetts, and Rhode Island. NRS. 55 : U.S. Department of Agriculture, Forest Service, Northern Research Station, Newtown Square, Pennsylvania, USA.

Cooper, T.R., and R.D. Rau. 2013. American woodcock population status - 2013. U.S. Fish and Wildlife Service, Laurel, Maryland, USA.

Daniels, S.E., M.A. Kilgore, M.G. Jacobson, J.L. Greene, and T.J. Straka. 2010. Examining the compatibility between forestry incentive programs in the US and the practice of sustainable forest management. Forests 1:49-64.

Dettmers, R., and K.V. Rosenberg. 2000. Partners in Flight landbird conservation plan: Physiographic Area 9: southern New England. Partners in Flight. Available at http://www.partnersinflight.org/bcps/pifplans.htm.

Kelley, J., S. Williamson, and T.R. Cooper, editors. 2008. American woodcock conservation plan. Wildlife Management Institute. Available at: http://timberdoodle.org/, Cabot, Vermont, USA. 
[3] COMmUniCATION STRATEgIES • Proceedings of the Eleventh American Woodcock Symposium

Ma, Z., B.J. Butler, D.B. Kittredge, and P. Catanzaro. 2012. Factors associated with landowner involvement in forest conservation programs in the U.S.: implications for policy design and outreach. Land Use Policy 29:53-61.

Masse, R.J., B.C. Tefft, J.A. Amador, and S.R. McWilliams. 2013. Why woodcock commute: testing the foraging-benefit and predation-risk hypotheses. Behavioral Ecology 24:1348-1355.

Masse, R.J., B.C. Tefft, and S.R. McWilliams. 2014. Multiscale habitat selection by a forest-dwelling shorebird, the American woodcock: implications for forest management in southern New England, USA. Forest Ecology and Management 325:37-48.

Masse, R.J., B.C. Tefft, and S.R. McWilliams. 2015. Higher bird abundance and diversity where American woodcock sing: fringe benefits of managing forests for woodcock. The Journal of Wildlife Management 79:1378-1384.

McAuley, D.G., J.R. Longcore, D.A. Clugston, R.B. Allen, A. Weik, S. Williamson, J. Dunn, B. Palmer, K. Evans, W. Staats, G.F. Sepik, and W.W. Halteman. 2005. Effects of hunting on survival of American woodcock in the Northeast. Northeast Journal of Wildlife Management 69:1565-1577.

Monahan, E. 2012. American woodcock habitat management and development of a woodcock habitat demonstration area trail. University of Rhode Island, Kingston, Rhode Island, USA.
Availalble at http://web.uri.edu/forestry/files/2017/o8/Monahan-2012-Development-of-Woodcock-Habitat-Demonstration-Area-Trail.pdf.

NRCS. 2017. Natural Resources Conservation Service. <https://www. nrcs.usda.gov/wps/portal/nrcs/main/ri/programs/financial/ eqip/>. Accessed 1 Aug 2017.

Poudyal, N.C., and D.G. Hodges. 2009. Factors influencing landowner interest in managing wildlife and avian habitat on private forestland. Human Dimensions of Wildlife 14:240-250.

Rickenbach, M., and D. Kittredge. 2009. Time and distance: comparing motivations among forest landowners in New England, USA. Small-Scale Forestry 8:95-108.

RIGIS. 2017. Rhode Island Geographic Information System. <http:// www.rigis.org/>. Accessed 1 Aug 2017.

URI. 2017. University of Rhode Island, Department of Natural Resources Science. Kingston, Rhode Island, USA. <http:// web.uri.edu/forestry/rhode-island-woods-website/>. Accessed 1 Aug 2017.

Williamson, S. 2008. Bird Conservation Region 30: New England/ Mid-Atlantic Coast. Pages 138-147 in J. Kelley, S. Williamson, and T.R. Cooper, editors. American Woodcock Conservation Plan. Wildlife Management Institute, Cabot, Vermont, USA. Available at: http://timberdoodle.org/. 


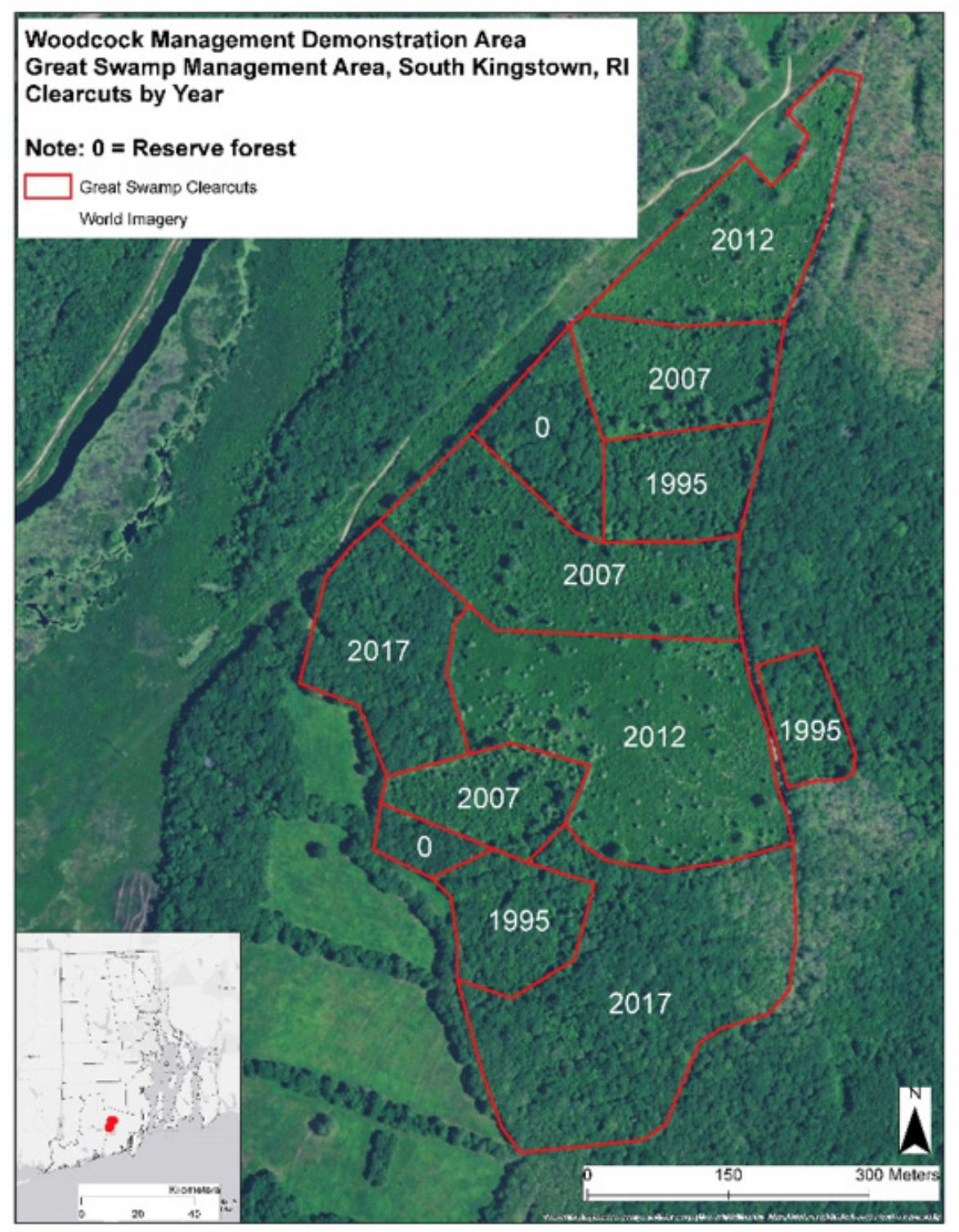

Figure 1. Location of young forest patches produced by the Rhode Island Department of Environmental Management Division of Fish and Wildlife during 1995 to 2017 as part of the creation of an ca. 40-ha woodcock management demonstration area in the state-owned Great Swamp Wildlife Management Area, South Kingstown, Rhode Island, USA. 


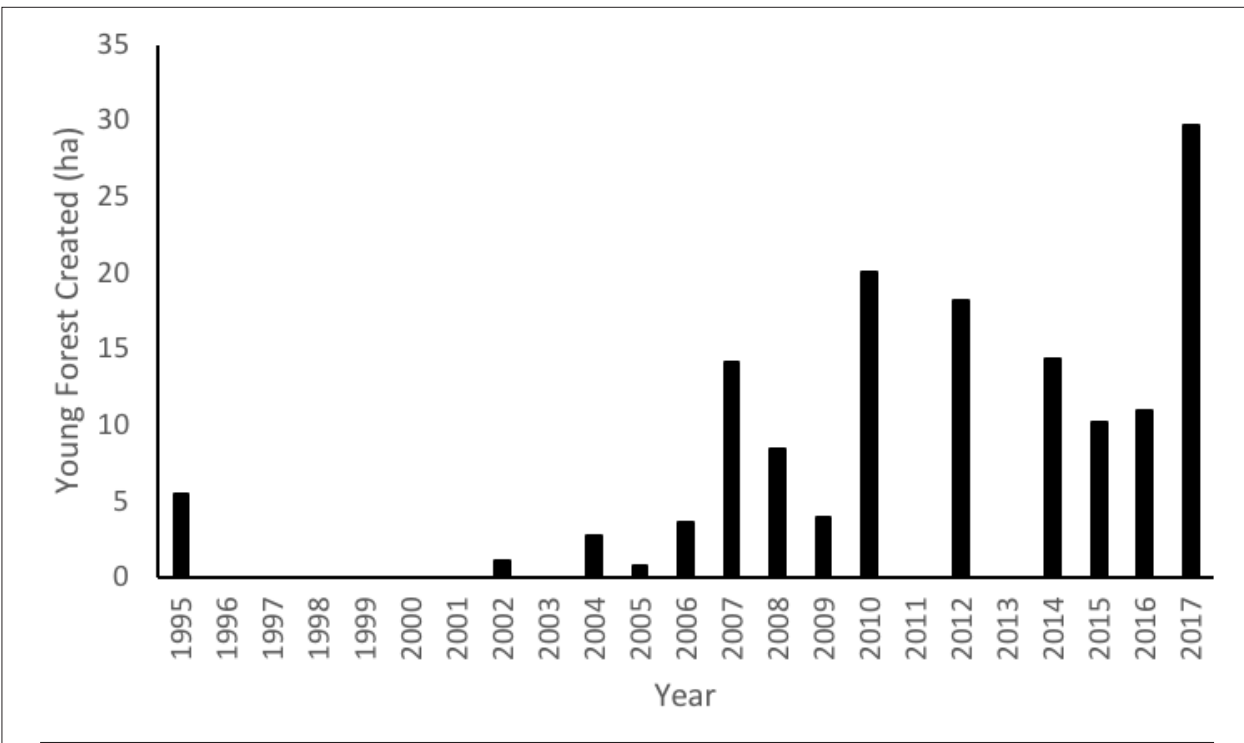

Figure 2. Total amount (ha) of young forest produced by Rhode Island Department of Environmental Management Division of Fish and Wildlife on state-owned land during 1995 to 2017 in Rhode Island, USA.

\section{Roosting Fields}

In the summer and early fall, when woodcock are no longer seeking mates but have not yet migrated south, they often fly to forest openings each night to roost. Woodcock will roost in old fields and pastures,

blueberry barrens, or newly created clear cuts. While these areas may not be rich in food for the woodcock, they do provide safety from predators. The patchy growth in these habitats provides protection from predators overhead, but is open enough to permit good vision of potential predators approaching on the ground. Research conducted by biologists with the Division of Fish and Wildlife and the University of Rhode Island show evidence that at night woodcock are safer in fields or recent clear cuts than dense forest

because mammalian predators are less active in these forest openings. Young of the year will begin moving to these roost sites about 3 weeks after hatching, when they are independent of their mother.

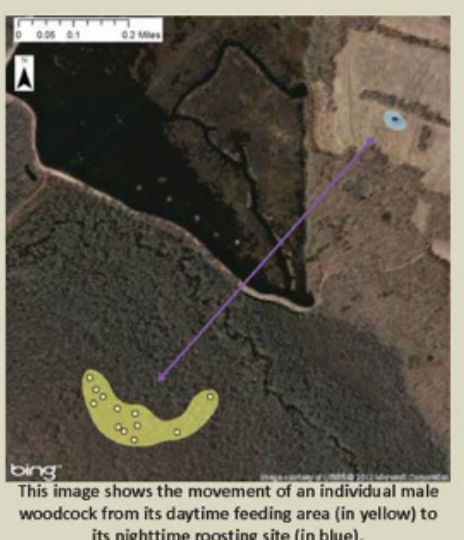
its nighttime roosting site (in blue).

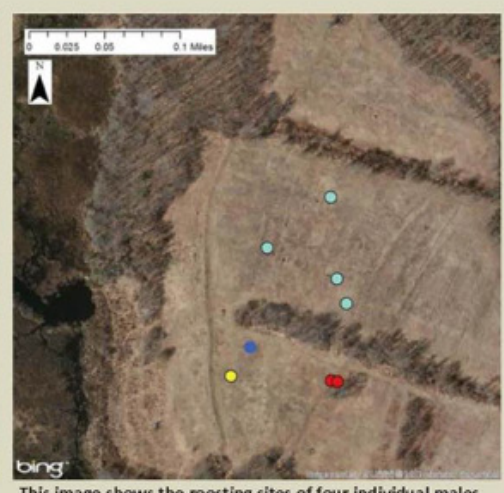

This image shows the roosting sites of four individual males, each marked by a different color.

The field that you are in has been managed to create roosting habitat for woodcock. Each year during July, managers at the Great Swamp Management Area mow a series of 8-20ft wide strips throughout the field and along the field edges. Woodcock roost in the shorter grass that has been mowed, and radio tracking of woodcock has shown that some individuals will consistently return to these mowed areas each night.

Managers recommend periodically mowing whole fields and meadows or a series of 20 foot wide strips from mid-July through September to encourage woodcock roosting.

Figure S1. Design of an interpretive sign for the woodcock management demonstration area in the state-owned Great Swamp Wildlife Management Area, South Kingstown, Rhode Island, USA. 